\title{
Epidemiological analysis of cases of uveitis in a tertiary Hospital
}

\section{Análise Retrospectiva e Caracterização Epidemiológica dos casos de Uveíte em hospital terciário}

Aluisio Rosa Gameiro Filho', Aline Fernandes de Albuquerque1, Diogo Gonçalves dos Santos Martins¹, Daniella Socci da Costa ${ }^{1}$

\begin{abstract}
Objective: To analyze the distribution of uveitis in patients at Uveitis Sector of Federal Hospital of Servants of Rio de Janeiro State. Methods: Retrospective epidemiological study of 63 appointments performed by ophthalmologist of Uveitis Sector at Federal Hospital of Servants of Rio De Janeiro State, between March and October of 2016. Results: The mean age was $45.54( \pm 15.8) .50 .5 \%$ were female. Anterior uveitis corresponded to $63.49 \%$. Only $33.3 \%$ of patient had an active inflammation at the moment of medical avaliation. $74.6 \%$ of uveitis had non-infeccious causes, and in 12.69\% the etiology could not be determined. Ankylosing spondylitis was the most frequent cause, responsible for $28.57 \%$ of cases. $55.5 \%$ of patients had a bilateral uveitis, and $71.14 \%$ non-granulomatous uveitis. Conclusions: Epidemiological studies about uveitis are usually made in terciary hospitals, which do not reflect the epidemiological profile of population in general.
\end{abstract}

Keywords: Uveitis/etiology; Uveitis/epidemiology; Uveitis/classification; Ocular inflammation; Retrospective study

\section{RESUMO}

Objetivo: Analisar a distribuição dos casos de uveíte em pacientes atendidos no Setor de Uveíte do Serviço de Oftalmologia do Hospital Federal Servidores do Estado do Rio de Janeiro. Métodos: Estudo epidemiológico retrospectivo, transversal e descritivo pela análise de prontuários de 63 pacientes atendidos no Serviço de Oftalmologia do Hospital Federal dos Servidores do Estado do Rio de Janeiro, no Setor de Uveíte, no período de Março a Outubro de 2016. Resultados: A média de idade foi de 45,54 $( \pm 15,8)$, sendo $50,8 \%$ do sexo feminino e $49,2 \%$ do masculino. Uveítes anteriores corresponderam à $63,49 \%$ dos casos, intermediárias $1,58 \%$ posterior $19,04 \%$ e panuveíte $15,87 \%$. Apenas $33,3 \%$ dos pacientes encontravam-se com processo inflamatório ativo no momento da avaliação. Cerca de 74,6\% das uveítes tinham causas não infecciosas e em $12,69 \%$ não foi possível a determinação etiológica. A causa isolada mais frequente foi Espondilite Anquilosante, responsável por 28,57\% dos casos. Demonstrou-se que 55,5\% dos pacientes tinham acometimento bilateral e 71,14\% apresentavam uveíte não granulomatosa. Conclusões: Estudos epidemiológicos que tratam de uveíte são, em geral, realizados em centros terciários de atendimento, que por vezes apresentam perfil etiológico destas inflamações intra-oculares diferente da população geral.

Descritores: Uveíte/etiologia; Uveíte/epidemiologia; Uveíte/classificação; Inflamação intraocular; Estudo retrospectivo.

${ }^{1}$ Hospital Federal dos Servidores do Estado do Rio de Janeiro, Rio de Janeiro, RJ, Brazil.

The authors declare no conflicts of interests.

Received for publication 12/02/2017 - Accepted for publication 22/06/2017. 


\section{INTRODUCTION}

$\mathbf{U}$ veitis is an inflammatory intraocular process involving the uvea and surrounding structures, being responsible for $4 \%$ of the visits to ophthalmological emergency services $^{(1)}$ and a major cause of visual loss both in developed and underdeveloped countries. ${ }^{(2)}$

It is estimated to be responsible for 5 to $20 \%$ of cases of visual loss in the United States, ${ }^{(3)}$ for 3 to $7 \%$ in European countries, and for 3 to $10 \%$ in developing countries 2 . The world literature reports great variations in the etiology of uveitis ${ }^{(4)}$ These differences can not be explained only by socioeconomic disparities or access to health services, since factors such as age, gender, race, occupation, life habits and geographic origin can influence them, being this point the importance of epidemiological studies on the etiology of these inflammatory processes. In addition, the comparison between studies performed in different regions of the world and at different times allows us to establish trends and speculate relevant factors to the etiopathogenesis of this disease.

In the absence of a similar study conducted in Rio de Janeiro, and considering that the city is the second largest urban center in Brazil, the present study aims at analyzing the distribution of uveitis in patients treated at the Uveitis Sector of the Ophthalmology Service of Hospital Federal dos Servidores do Estado do Rio de Janeiro.

\section{Methods}

A retrospective, cross-sectional and descriptive epidemiological study was carried out to analyze the medical records of 63 patients treated at the Uveitis Sector of the Ophthalmology Service of Hospital Federal dos Servidores do Estado do Rio de Janeiro from March to October 2016.

All patients treated in this Sector underwent anamnesis and complete ophthalmologic examination, including assessment of visual acuity, facial ectoscopy, anterior and posterior biomicroscopy, intraocular pressure measurement by aplanation tonometry, and indirect fundoscopy. All patients had fundoscopy assessment performed after adequate pupillary dilation to avoid the spill-over phenomenon, that is, so that the presence of cells in the anterior chamber secondary to retinal inflammation was not erroneously interpreted as anterior uveitis. Further ocular and systemic examinations were performed according to the need, clinical development and diagnostic hypothesis.

Variables like age, gender, etiological and anatomical diagnosis, disease activity, laterality, ocular complications, final visual acuity, and systemic comorbidities of the patient were analyzed. Regardless of the number of visits, each patient was counted only once in the period established by the study in question.

The classification used followed the criteria set out by the International Uveitis Study Group, adapted by SUN (Standardization of Uveitis Nomenclature). It was considered an active disease when there were cells and flare in the anterior chamber, Keratic precipitate (KPs), hypopio, iris nodules, anterior or posterior synechiae, vitreous cells, snowballs, snowbanks, inflammatory lesions in the retina or choroid, vasculitis associated with symptoms such as pain, red eye, photophobia, decreased visual acuity, flying flies, pericytic or limbic hyperemia.

Patients with ocular inflammation in a short postoperative or post-trauma period and with endophthalmitis were excluded from the analysis.
For the calculation of the best corrected visual acuity, the conversion of the Snellen scale to the Log-MAR scale was made. The results collected from the forms were submitted to descriptive statistical treatment by means of percentages, being all data broken down through charts and graphs.

\section{Results}

The medical records of all patients treated in the Uveitis sector of Hospital Federal dos Servidores do Estado de Rio de Janeiro (HFSE) from March to October 2016 were evaluated, being $49.2 \%$ men and $50.8 \%$ women. The age ranged from 3 to 73 years, with an average of $45.54( \pm 15.8)$, with the following distribution: $7 \%$ of patients up to 16 years, $28.5 \%$ between 17 and 40 years, and $63.5 \%$ over 40 years. The visual acuity (VA) varied widely from 20/20 (logMAR 0 ) to no light perception (NLP). Regarding the origin, $93.6 \%$ of patients lived in the city of Rio de Janeiro, $4.8 \%$ were from other cities of the state of Rio, and $1.6 \%$ were from other states of Brazil.

Using the anatomical diagnosis classification, we found $63.5 \%$ of anterior uveitis, $1.6 \%$ intermediate, $19.04 \%$ posterior, and $15.87 \%$ panuveitis. The prevalence of anterior uveitis in all age groups was studied, being $100 \%$ in individuals up to 16 years of age, $61.1 \%$ from 17 to 40 years, and $60 \%$ over 40 years.

As for the activity of the ocular disease during treatment, $33.3 \%$ of cases presented active disease, and $66.6 \%$ were with no activity. Regarding laterality, $44 \%$ had unilateral involvement, with the right eye being affected in $23.8 \%$ of cases. Other $56 \%$ of patients had binocular involvement.

The etiological diagnosis of the disease was possible in $87.3 \%$ of the cases, being it the most frequent etiologies: (Figure 1) Ankylosing Spondylitis with $28.5 \%$ of cases, followed by Toxoplasmosis with 9.5\%, and Psoriatic Arthritis and Behçet's Disease, both with $7.9 \%$ of cases. Other causes were found: Vogt-Koyanagi-Harada disease (VKHD) with $6.3 \%$, Juvenile Idiopathic Arthritis (JIA) and Sarcoidosis with $4.8 \%$ each, Crohn's Disease with $3.1 \%$, and Rheumatoid Arthritis, Wegener's Granulomatosis, Takayasu's Arteritis, Reactive Arthritis, Polychondritis, Syphilis, Tuberculosis, and Arteritis of Giant Cells with $1.6 \%$ each. Idiopathic or undetermined causes corresponded to $12.7 \%$ of cases.

According to the clinical aspect, $10 \%$ of cases were classified as granulomatous uveitis, $71 \%$ non-granulomatous, and in $19 \%$ of cases it was not possible to classify.

Regarding the clinical development of the inflammatory condition, $42.8 \%$ were classified as acute, $11.1 \%$ as chronic cases, $33.3 \%$ as recurrent, and $12.7 \%$ could not be determined.

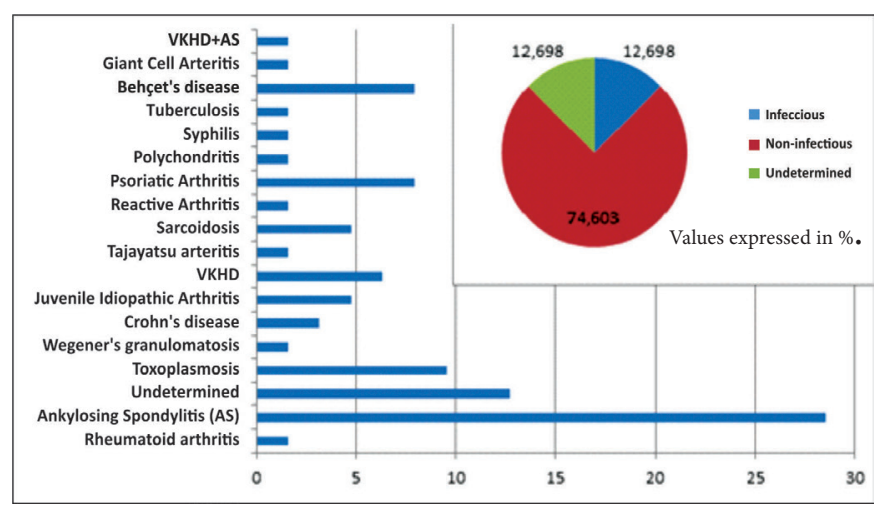

Figure 1. Etiology of uveitis 
Analyzing the associated comorbidities, we obtained $28.57 \%$ of cases with a diagnosis of systemic arterial hypertension, $4.76 \%$ with Diabetes Mellitus, $3.17 \%$ with hypothyroidism, and $3.17 \%$ HIV-positive patients. We also found patients with Hepatitis B, Atrial Fibrillation, Systemic Lupus Erythematosus, Rheumatic Fever, Toxoplasmosis, Syphilis, Coronary Artery Disease, Depression, Panic Syndrome, Scleroderma, Crohn's Disease, Rheumatoid Arthritis, and Asthma.

Finally, we observed ocular complications due to ocular inflammation. $30.15 \%$ of the cases evolved with cataracts, $15.87 \%$ with posterior synechiae, $11.11 \%$ with retinal detachment, $7.93 \%$ with glaucoma, $4.76 \%$ with corneal edema, $3.17 \%$ with epiretinal membrane, $3.17 \%$ with cystoid macular edema, $3.17 \%$ with keratic precipitate. It corresponds to $1.58 \%$ of cases in each group of patients which evolved with macular atrophy, venous occlusion, corneal neovascularization, and posterior capsule opacity.

When only cases of anterior uveitis were evaluated, and with $52.5 \%$ of cases being males with an average age of $45.15( \pm 7.2)$, only $20 \%$ of cases showed active disease in the evaluation. $45 \%$ of the cases were classified as acute disease, $30 \%$ as recurrent, $10 \%$ as chronic, and $15 \%$ could not be determined. The involvement was bilateral in 55\% of cases. Regarding the clinical aspect, $77.5 \%$ were non-granulomatous, $5 \%$ were granulomatous, and $30 \%$ of cases could not be classified. Regarding the etiology, $85 \%$ presented non-infectious uveitis, and in $15 \%$ of cases it was not possible to determine the specific cause. The main cause alone was undoubtedly Ankylosing Spondylitis, responsible for $40 \%$ of cases, followed by undetermined cause with $15 \%$, Psoriatic Arthritis with $12.5 \%$, Behçet's Disease with $10 \%$, Juvenile Idiopathic Arthritis with $7.5 \%$, and Crohn's disease with $5 \%$. It corresponds to $2.5 \%$ of each etiologic group in which Rheumatoid Arthritis, Takayasu's Arteritis, Reactive Arthritis, and Polychondritis are included.

When we analyzed patients with posterior uveitis, we noticed that $66.6 \%$ of patients were male, with an average age of $45.18( \pm 2.49)$, and $50 \%$ of them presented active disease during the ophthalmologic treatment. Infectious causes were the main responsible $(50 \%)$, and toxoplasmosis was the main one, with 6 patients affected. $83.3 \%$ of cases were classified in the clinical profile as being non-granulomatous.

Regarding panuveitis, we found an average age of 47.3 years $( \pm 14.86)$, and $80 \%$ of the affected patients were women with active disease in $60 \%$ of cases. Regarding the etiology, $80 \%$ of cases were identified as non-infectious, and $20 \%$ infectious. The main isolated causes were Vogt-Koyanagi-Harada Disease with $40 \%$ of cases, and Sarcoidosis with 20\%. Syphilis, Tuberculosis, Behçet's Disease, and concomitant VKHD and Ankylosing Spondylitis were responsible for $10 \%$ each.

We had only one case of intermediate uveitis of undetermined cause in our study.

Gender was also analyzed. Among the male patients we obtained an average age of 45 years $( \pm 17.6)$, with $67.74 \%$ of cases being of anterior uveitis, followed by $25.8 \%$ of posterior, and $6.45 \%$ of panuveitis. During the assessment, $67.74 \%$ of patients did not present active disease. The involvement was bilateral in $51,6 \%$ of patients. Regarding classification, $77.4 \%$ of uveitis were non-granulomatous. The main cause of ocular inflammation etiology was Ankylosing Spondylitis with $38.7 \%$ of cases, followed by Toxoplasmosis with $12.9 \%$, Wegener's Granulomatosis and JIA with $9.7 \%$, Sarcoidosis, Psoriatic Arthritis and Behçet's Disease with $6.5 \%$ each, Reactive Arthritis and Syphilis with $3.23 \%$ each, as shown in figure 2 .

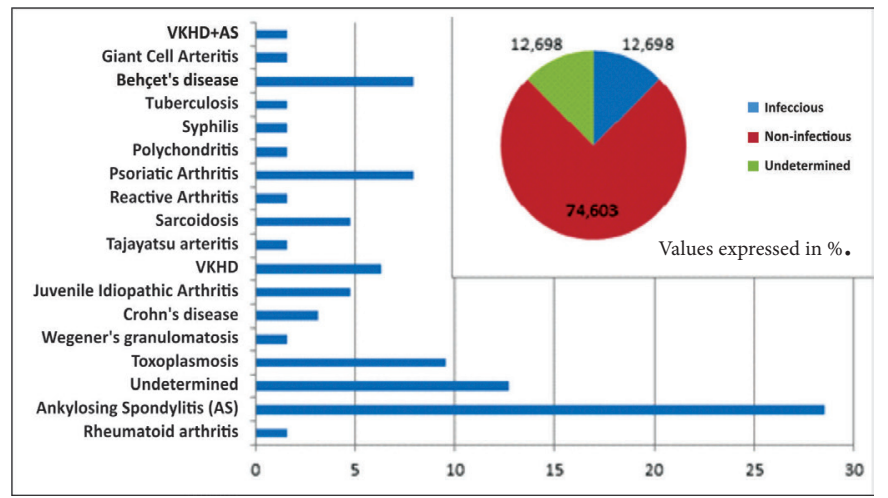

Figure 2. Etiology of uveitis in men

Among the group comprising women (Figure 3), the average age was 46.05 ( \pm 14.10$)$, with $59.4 \%$ represented by anterior uveitis, $25 \%$ by panuveitis, $12.5 \%$ by posterior, and $3.1 \%$ by intermediate uveitis. The main etiologies found were indeterminate cause with $18.8 \%$, Ankylosing Spondylitis also with 18.8\%, VKHD with $12.5 \%$, Behçet's Disease and Psoriatic Arthritis with 9.4\% each, and Toxoplasmosis with $6.25 \%$. Rheumatoid Arthritis, Crohn's Disease, Takayasu's Arteritis, Sarcoidosis, Polychondritis, Tuberculosis, Giant Cell Arteritis, and an association between DVKH and Ankylosing Spondylitis contributed with 3.13\% each.

An etiological analysis by age was also performed, as shown in figures 4,5 and 6.

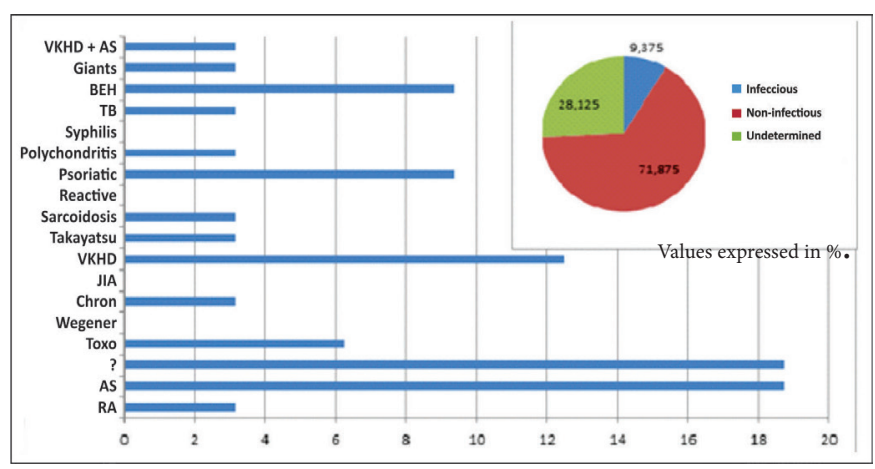

Figure 3. Etiology of uveitis in women

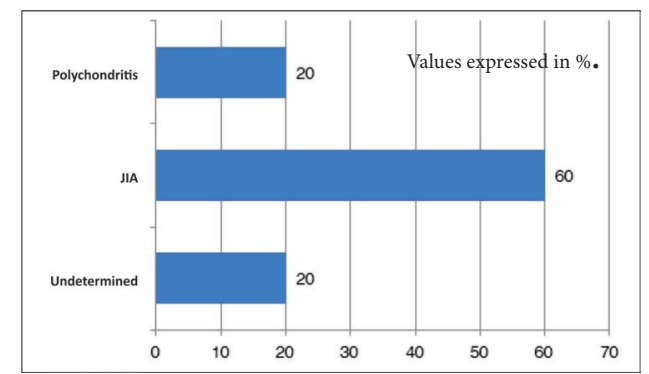

Figure 4. Etiology of uveitis in children under 16 years

\section{Discussion}

Epidemiological studies on the incidence of uveitis are important for the planning of health actions, since they contribute to the establishment of the pattern of diseases, which is quite heterogeneous and vary according to the place and time. 


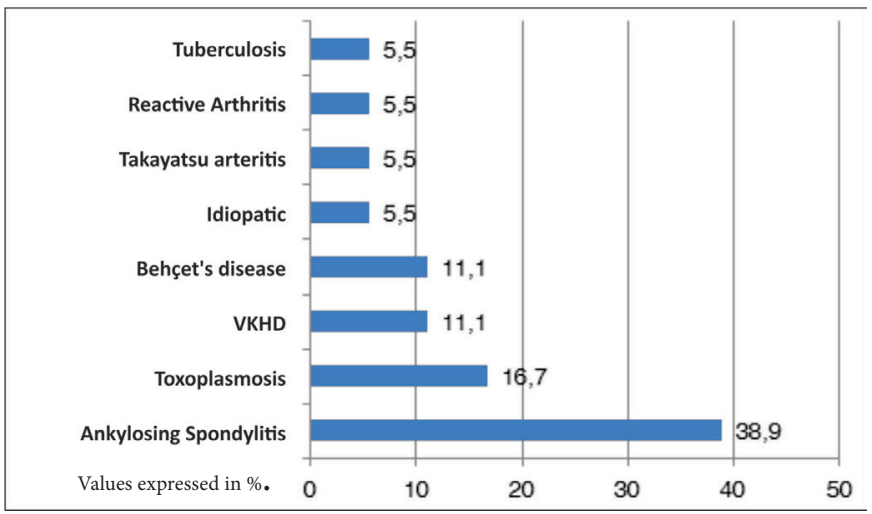

Figure 5. Etiology of uveitis at the age group from 17 to 40 years

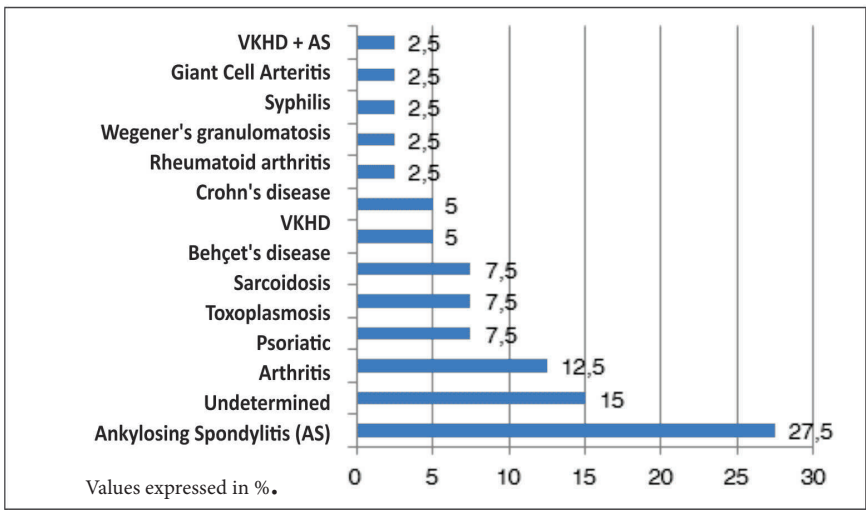

Figure 6. Etiology of uveitis in people over 40 years

Uveitis most commonly affects young adults ${ }^{(5)}$. Previous studies have shown that $60-80 \%$ of patients with uveitis have an average age between 35-45 years of age, ${ }^{(5)}$ which corresponds to the findings in our study, in which we obtained an average age of 45 years.

Regarding gender, previous studies have demonstrated a similar prevalence of uveitis in men and women, or even a slight predominance in women, especially in developed countries. Some studies in underdeveloped countries show a predominance of males, ${ }^{(5,6)}$ mainly in nations with a large rural population in which men are at higher risk developing certain types of uveitis, predominantly the infectious ones, due to etiologies such as Leptospirosis and Onchocerciasis. In addition, some conditions such as HLA-B27-related uveitis are associated with Ankylosing
Spondylitis, and are also more frequent in males. ${ }^{(7)}$ In our study, we found a similar overall prevalence of uveitis in both genders.

As for the primary site of infection, most literature reports refer to anterior uveitis as the most frequent one, followed by posterior, diffuse and intermediate. However,said studies are frequently questioned by the possible Routing Bias, that is, as they are usually carried out in tertiary centers such as ours, in which patients followed would have a different etiological profile due to their diverse comorbidities and the reference services available, sometimes they would not reflect the etiological pattern of the general population.A study carried out in the United States in $1996^{(3)}$ compared the etiology of uveitis in a tertiary center to that in community clinics, with divergent results.

Our hospital is one of the main Ophthalmology reference centers in Rio de Janeiro, treating patients not only from the capital, but also from the metropolitan region of the State. In addition, the Ophthalmology Sector of our hospital receives direct referral from patients of the Rheumatology Service, which seems to explain our high prevalence of patients with previous uveitis (63.49\%), as well as the fact that the main isolated cause of uveitis in the present study being Ankylosing Spondylitis. In addition, some patients with retinal diseases as a consequence of posterior uveitis of etiologies such as Toxoplasmosis or Cytomegalovirus are referred directly to the Retina Sector of our service, which may have contributed to this high rate of anterior chamber disorders.

In our study we found a similar prevalence between bilateral and unilateral involvement, confirming the trend in the literature. ${ }^{(8,9)}$ However, in some countries such as Japan, in which causes such as Behçet's Disease or VKHD ${ }^{(10,11)}$ have a high incidence, there is a large predominance of bilateral involvement.

Similarly, $71.4 \%$ of our patients have no granulomatous uveitis, which also predominates in literature, ranging from $51-89 \%$ in previous reports. ${ }^{(5)}$

Epidemiological studies dealing with uveitis are mostly carried out in tertiary centers, which could be associated to a referral bias, that is, the presence of rheumatologic services in these hospitals and the ease of direct referral to Ophthalmology could increase the rate of rheumatological etiologies in the sample, thus not reflecting the prevalence found in the general population. In addition, it has been previously demonstrated that in the same place there is a change in the etiological pattern of these ocular inflammations when comparing different observation periods. ${ }^{(8,9)}$

The present retrospective study analyzed the distribution of cases of uveitis in a tertiary service, allowing a high prevalence of anterior uveitis, especially those of rheumatological origin, to be observed, unlike previous reports in the literature in underdeveloped countries, thus resembling more the profile found in developed countries, as shown in table 1.

Table 1

Comparison between etiological studies of uveitis

\begin{tabular}{|c|c|c|c|c|c|c|c|c|c|c|c|c|c|c|}
\hline Study & $\mathbf{N}$ & $\begin{array}{c}\text { Average } \\
\text { age }\end{array}$ & M:H & $\begin{array}{l}\text { Location } \\
\text { Anterior }\end{array}$ & Intermediate & Posterior & Diffuse & $\begin{array}{r}\text { C } \\
\text { Acute }\end{array}$ & $\begin{array}{l}\text { hronicity } \\
\text { Chronic }\end{array}$ & ' Recurrent & Not defined & Idiopatic & $\begin{array}{c}\text { Etiology } \\
\text { Infeccious }\end{array}$ & Non-infectious \\
\hline Rio de Janeiro & 63 & 45.54 & $1.03: 1$ & 63.49 & 1.58 & 19.04 & 15.87 & 42.85 & 11.11 & 33.33 & 12.69 & 12.69 & 12.29 & 74.6 \\
\hline Curitiba, Brazil 199911 & 68 & NA & NA & 22 & 0 & 49 & 29 & NA & NA & NA & NA & NA & NA & NA \\
\hline Teresina, Brazil $2016^{12}$ & 403 & 42 & $1.02: 1$ & 36 & 3.5 & 49.6 & 10.9 & 41.4 & 30.8 & 14.4 & 13.4 & 40.7 & 48.5 & 10.8 \\
\hline São Paulo, Brazil 2004¹ & 262 & 41 & $1.5: 1$ & 20 & 4.5 & 39.7 & 31.3 & NA & NA & NA & NA & 20.6 & 32 & 47.4 \\
\hline Tunis, Tunisia $2013^{13}$ & 424 & 36 & $1.5: 1$ & 48 & 5 & 13.3 & 33.6 & NA & NA & NA & NA & 48.11 & 19.1 & 32.79 \\
\hline Monastir, Tunisia $2007^{14}$ & 472 & 34 & 01:01 & 35.2 & 15.5 & 28.2 & 21.2 & NA & NA & NA & NA & 35.2 & 29 & 71 \\
\hline Saudi Arabia $2002^{15}$ & 200 & 38 & $0.6: 1$ & 59.5 & 6.5 & 13.5 & 20.5 & NA & NA & NA & NA & 43 & 36 & 21 \\
\hline Chennai, India $1996^{16}$ & 1273 & 40 & $0.6: 1$ & 39.3 & 17.4 & 28.8 & 14.5 & NA & NA & NA & NA & 59.3 & 11.9 & 28.8 \\
\hline Barcelona, Spain $2012^{17}$ & 416 & 48 & $1.12: 1$ & 36 & 9 & 31 & 24 & NA & NA & NA & NA & 20 & 31 & 49 \\
\hline Lisbon, Portugal $2013^{18}$ & 151 & 53.8 & $1.5: 1$ & 51.2 & 3.9 & 19.7 & 21.3 & NA & NA & NA & NA & 27 & 30 & 43 \\
\hline $\begin{array}{l}\text { Rotterdam, Netherlands } \\
1993\end{array}$ & 750 & NA & $1.09: 1$ & 52 & 9 & 24 & 15 & NA & NA & NA & NA & 40.5 & 17.8 & 42.5 \\
\hline Verona, Italy $2001^{20}$ & 655 & 4.1 & 01:01 & 58 & 2.9 & 26.1 & 12.9 & NA & NA & NA & NA & 46.1 & 40.3 & 13.6 \\
\hline Lausanne, Switzerland ${ }^{21}$ & 1995 & 435 & 43 & $0.7: 1$ & 62 & 11 & 207 & NA & NA & NA & NA & 35 & 30.6 & 34.4 \\
\hline
\end{tabular}


Despite the constant developments in Ophthalmology and its diagnostic methods, many cases still do not have a defined etiologic diagnosis, as demonstrated in this study, in which $12.69 \%$ of the patients were classified as having an idiopathic or indeterminate etiology. Although still high, the rate is lower than that found in similar reports in the literature. ${ }^{(5)}$

The sample of patients captured at this particular period of time may not have been large enough for us to surprise patients with more rare forms or etiologies of uveitis.

\section{Conclusion}

Epidemiological studies dealing with the subject of uveitis are relevant as they help identify the epidemiological profile of this disease in Brazil, and this is key for establishing priorities with regard to education, population care, and ophthalmologic research. However, studies in tertiary centers are limited in this aspect by sample biases. The most suitable would be studies covering not only tertiary health centers, but also secondary services, which would allow a better evaluation of the epidemiological reality of this disease in the country.

\section{ReFERENCES}

1. Gouveia EB, Yamamoto JH,Abdalla M, Hirata CE, Kubo P, Olivalves E. Causas de uveítes em serviço terciário em São Paulo, Brasil. Arq Bras Oftalmol. 2004; 67(1):139-45.

2. Rao NA. Uveitis in developing countries. Indian J Ophthalmol. 2013;61(6):253-4.

3. McCannel CA, Holland GN, Helm CJ, Cornell PJ, Winston JV, Rimmer TG. Causes of uveitis in the general practice of Ophthalmology. Am J Ophthalmol. 1996;121(1):35-46.

4- Woods AC. Modern concepts of the etiology of uveitis. Am J Ophthalmol. 1960;50:1170-87.

5- Rathinam SR, Namperumalsamy P. Global Variation and pattern changes in epidemiology of uveitis. Indian J Ophthalmol. 2007;55(3):173-83.

6. Consul BN, Sharma DP,Chhabra HN, Sahai R. Uveitis: etiological pattern in India. Eye Ear Nose Throat Mon. 1972;51(3):122-7.

7. Biziorek B, Mackiewicz J,Zagórski Z, Krwawicz L Haszcz D. Etiology of uveitis in Rural and Urban areas of mid-eastern Poland. Ann Agric Environ Med. 2001;8(2):241-3.

8. James DG, Friedmann AI, Graham E. Uveitis - a series of 368 patients. Trans Ophthalmol Soc U K. 1976;96(1):108-12.
9. Wakabayashi T, Morimura Y, Miyamoto Y, Okada AA. Changing patterns of intraocular inflammatory disease in Japan. Ocul Immunol Inflamm. 2003;11(4):277-86.

10. Kotake S, Furudate N, Sasamoto Y, Yoshikawa K, Goda C, Matsuda H. Characteristics of endogenous uveitis in Hokkaido, Japan. Graefes Arch Clin Exp Ophthalmol. 1996;234(10):599-603.

11. Gehlen ML, Dabul VM, Obara SS, Grebos SP, Moreira CA. Incidência e etiologia de uveítem em Curitiba. Arq Bras Oftalmol.1999; 62(5):622-6.

12. Teixeira LP, Abrahão MM, Dália ERC, Campos LM, Junior JJN Fonseca VCD. Estudo da prevalência de uveítes em hospital oftalmolígico terciário em Teresina, Piauí, Brasil. Rev Bras Oftalmol. 2016;75(3):174-80

13. Chebil A, Baroudi B, Slim M, Chaker M, Lamloum M, Bouladi M, Houman H, El Matri L. Profil épidémiologique des uveítes dans la region de Tunis. J Fr Ophtalmol. 2013 Nov;36(9):764-8.

14. Khairallah M, Yahia SB, Ladjimi A, Messaoud R, Zaouali S, Attia S, Jenzeri S, Jelliti B. Pattern of uveitis in a referral centre inTunisia, North Africa. Eye (London).2007; 21(1):33-9.

15. Islam SM, Tabbara KF. Causes of uveitis at The Eye Center in Saudi Arabia: A retrospective review. Ophthalmic Epidemiol. 2002;9(4):239-49.

16. Biswas J, Narain S, Das D, Ganesh SK. Pattern of uveitis in referral uveitis clinic in India. Int Ophthalmol. 1996-1997;20(4):223-8.

17. Bélles VL, Civera AA, Garriga GE, Segura RC, Martinéz JG, Colás LP, et al. Caracterizacíon de las uveitis diagnosticadas en un centro de referencia del área de Barcelona. Med Clin (Barc) 2012;138(7):277-82

18. Lisboa M, Santos A, Vieira L, Rosa R, Cardoso M, Domingues I. Análise retrospective e caracterização epidemiológica de 151 casos de inflamação intraocular. Oftalmologia. 2007; 37(4):273-82.

19. Smit RL, Baarsma GS, de Vries J. Classification of 750 consecutive uveitis patients in the Rotterdam Eye Hospital. Int Ophthalmol. 1993;17(2):71-6.

20. Mercanti A, Parolini B, Bonora A, Lequaglie Q, Tomazzoli L. Epidemiology of endogenous uveitis in north-eastern Italy. Analysis of 655 new cases. Acta Ophthalmol Scand. 2001;79(1):64-8.

21. Tran VT, Auer C, Guex-Crosier Y, Pittet N, Herbort CP. Epidemiological characteristics of uveitis in Switzerland. Int Ophthalmol 1994-1995;18(5):293-8.

\section{Corresponding Author:}

Aluisio Rosa Gameiro Filho

Rua Vinícius de Moraes, 110 apartamento 608, Ipanema, Rio de Janeiro - RJ, Brasil. ZIP CODE: 22411-010

E-mail: agameirofilho@yahoo.com.br 